$$
\begin{array}{r}
y / \operatorname{suB}--96-99069 \mathrm{C} / \mathrm{y}_{22} / 2 \\
\text { Y/SUB/96-99069C/Y22/2 }
\end{array}
$$

\title{
SITE STATUS MONITORING REPORT FOR UNDERGROUND STORAGE TANK 0134-U AT BUILDING 9204-2
}

OAK RIDGE Y-12 PLANT OAK RIDGE, TENNESSEE FACILITY ID \#0-010117

March 1996

Environmental Management Department Health, Safety, Environment, and Accountability Organization 


\section{SCIENCE APPLICATIONS INTERNATIONAL CORPORATION}

contributed to the preparation of this document and should not be considered an eligible contractor for its review. 


\title{
SITE STATUS MONITORING REPORT FOR UNDERGROUND STORAGE TANK 0134-U AT BUILDING 9204-2
}

OAK RIDGE Y-12 PLANT

OAK RIDGE, TENNESSEE

FACILITY ID \#0-010117

\section{March 1996}

Environmental Management Department

Health, Safety, Environment, and Accountability Organization

\section{Prepared by}

Science Applications International Corporation Under Subcontract 22B-99069C

for the

Oak Ridge Y-12 Plant

Oak Ridge, Tennessee 37831

\author{
Managed by \\ Lockheed Martin Energy Systems, Inc. \\ for the \\ U.S. Department of Energy \\ Under Contract No. DE-AC05-84OR21400
}




\section{DISCLAIMER}

Portions of this document may be illegible in electronic image products. Images are produced from the best available original document. 


\section{TABLE OF CONTENTS}

\section{Page}

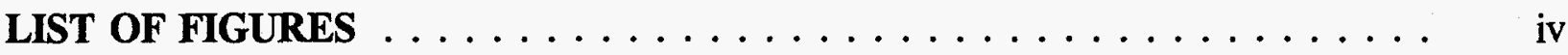

LIST OF TABLES $\ldots \ldots \ldots \ldots \ldots \ldots \ldots \ldots \ldots \ldots \ldots \ldots \ldots \ldots \ldots$ iv

LIST OF ACRONYMS $\ldots \ldots \ldots \ldots \ldots \ldots \ldots \ldots \ldots \ldots \ldots \ldots \ldots \ldots$ v

SIGNATURE PAGE $\ldots \ldots \ldots \ldots \ldots \ldots \ldots \ldots \ldots$ vi

CERTIFICATION PAGE $\ldots \ldots \ldots \ldots \ldots \ldots \ldots \ldots$ vii

SITE STATUS MONITORING REPORT

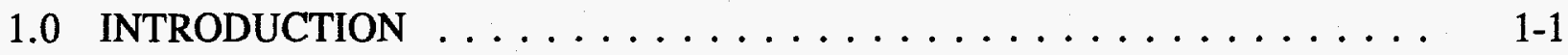

1.1 PURPOSE AND SCOPE $\ldots \ldots \ldots \ldots \ldots \ldots \ldots \ldots \ldots \ldots \ldots \ldots$

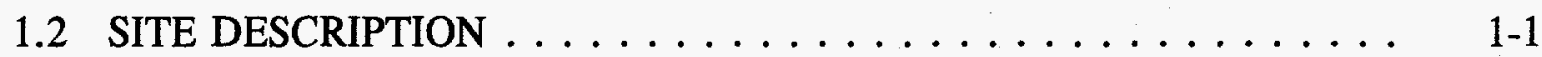

2.0 GROUNDWATER MONITORING $\ldots \ldots \ldots \ldots \ldots \ldots \ldots$ 2-1

2.1 GROUNDWATER MEASUREMENT, SAMPLE COLLECTION,

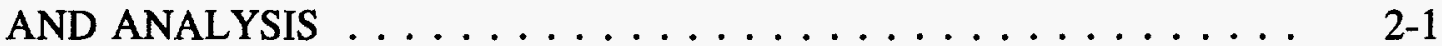

2.1 .1 Well Locations $\ldots \ldots \ldots \ldots \ldots \ldots \ldots \ldots . \ldots \ldots$ 2-1

2.1.2 Groundwater Measurement and Sampling ......... 2-1

2.1.3 Sample Analysis . . . . . . . . . . . . . 2-1

2.2 POTENTIOMETRIC DATA ............... 2-3

2.3 GROUNDWATER ANALYTICAL DATA $\ldots \ldots \ldots \ldots \ldots \ldots$

3.0 VAPOR MONITORING $\ldots \ldots \ldots \ldots \ldots \ldots \ldots \ldots \ldots \ldots \ldots \ldots$ 3-1

3.1 MONITORING METHODS AND LOCATIONS $\ldots \ldots \ldots \ldots \ldots$ 3-1

3.2 VAPOR MONITORING RESULTS $\ldots \ldots \ldots \ldots \ldots \ldots$. . . . . .

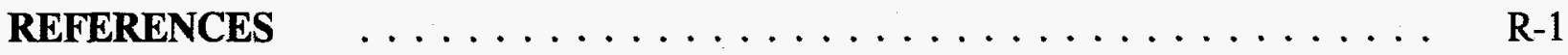

APPENDICES

APPENDIX A LABORATORY ANALYTICAL RESULTS FOR

SITE STATUS MONITORING GROUNDWATER SAMPLING • A-1 


\section{LIST OF FIGURES}

Figure Title

Page

1-1 Location of the Building 9204-2 Site at the Oak Ridge Y-12 Plant . . . . . 1-2

1-2 Building 9204-2 Site Map . . . . . . . . . . . . . . . . 1-3

2-1 Location of Groundwater Monitoring Wells at the Building 9204-2 Site . . . 2-2

2-2 Building 9204-2 Site Groundwater Potentiometric Contour Map,

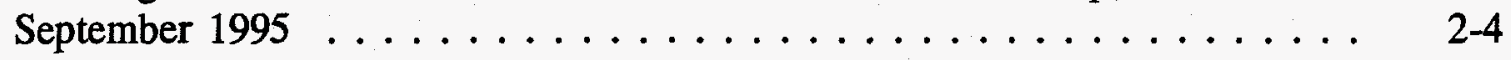

2-3 Building 9204-2 Site Groundwater Potentiometric Contour Map,

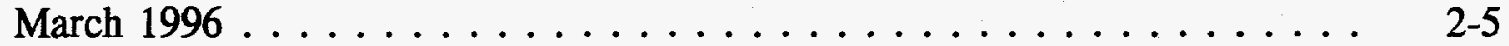

3-1 Organic Vapor Monitoring Points at the Building 9204-2 Site $\ldots \ldots \ldots$ 3-2

\section{LIST OF TABLES}

Table Title Page

2-1 Water Level Measurements at the Building 9204-2 Site for the Periods

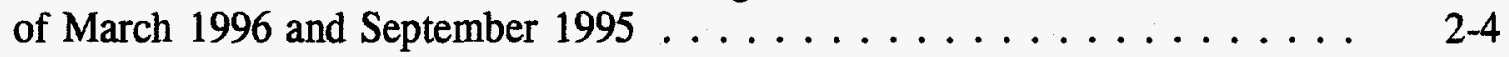

2-2 Analytical Results for Groundwater Samples Collected during Site Status and Comprehensive Monitoring, Site Ranking, and Baseline Sampling . . . 2 2-7

3-1 Vapor Monitoring Results for the Building 9204-2 Site, August 31, 1995 . . 3-1 


\section{LIST OF ACRONYMS}

BGS

BTEX

CAP

Energy Systems

LEL

TDEC

TGD

TPH-GRO

UEFPC

UST

EBTX below ground surface

benzene, toluene, ethylbenzene, and xylenes

Corrective Action Plan

Lockheed Martin Energy Systems, Inc.

lower explosive limit

Tennessee Department of Environment and Conservation

Technical Guidance Document

total petroleum hydrocarbons-gasoline range organics

Upper East Fork Poplar Creek

underground storage tank

total benzene, toluene, and xylenes 


\section{SIGNATURE PAGE}

\section{SITE STATUS MONITORING FOR THE BUILDING 9204-2 SITE}

I certify under penalty of law, including but not limited to penalties for perjury, that the information contained in this report and on any attachments, is true, accurate, and complete to the best of my knowledge, information, and belief. I am aware that there are significant penalties for submitting false information, including the possibility of fine and imprisonment for intentional violations.

See Attached Certification

Owner/Operator (Print)

$\overline{\text { Signature }} \overline{\text { Date }}$

William D. Keefer

P.E. or P.G. (Print)

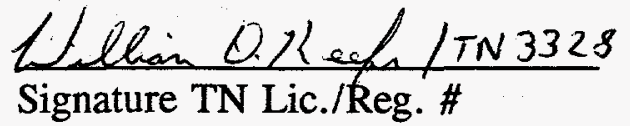

$3 / 20 / 96$

If a P.E. signs this report, please indicate the area of expertise.

(Print or Type)

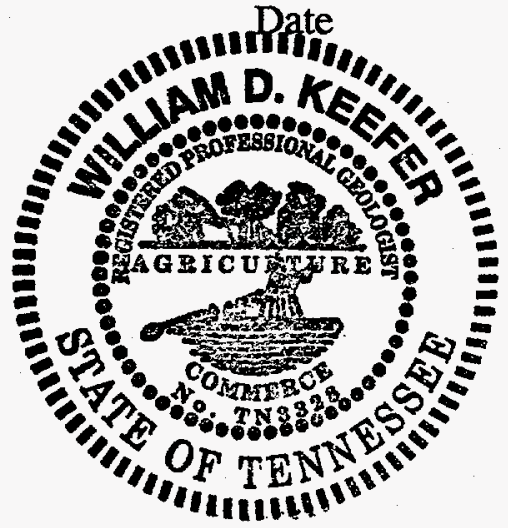

(P.E./P.G. Stamp/Seal)

County of Anderson State of Sennessel

Subscribed and Sworn to before me this

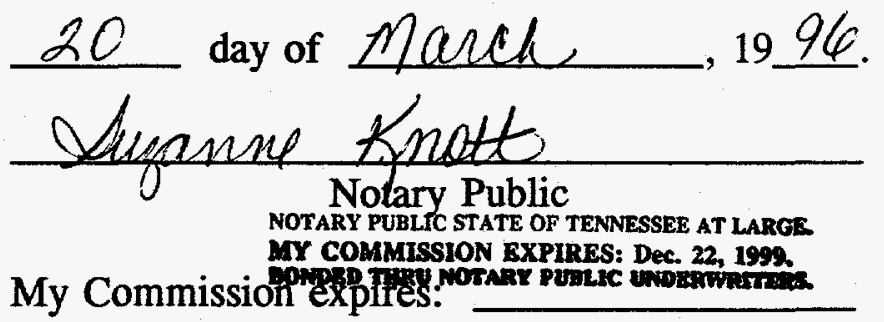

(Notary Seai) 


\section{CERTIFICATION STATEMENT}

\section{SITE STATUS MONITORING FOR THE BUILDING 9204-2 SITE FACILITY ID 0-010117}

I certify that this document and all enclosures were prepared under my direction or supervision in accordance with a system designed to ensure that qualified personnel properly gather and evaluate the information submitted. Based on my inquiry of the person or persons directly responsible for gathering the information, the information submitted is, to the best of my knowledge and belief, true, accurate, and complete.

\section{U.S. Department of Energy}

Owner and Operator

By:
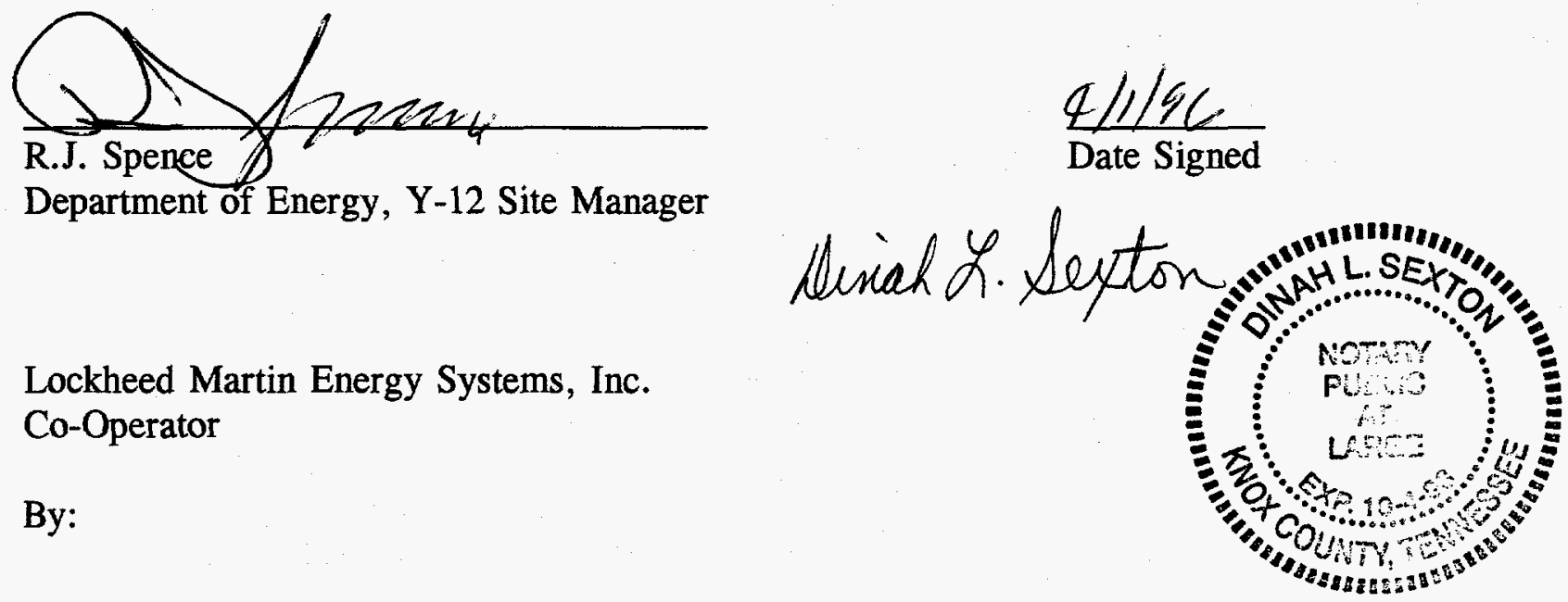

Department of Energy, Y-12 Site Manager

Lockheed Martin Energy Systems, Inc.

Co-Operator

By:

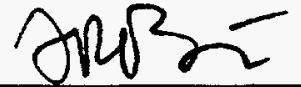

T.R. Butz

Lockheed Martin Energy Systems, Inc.

Y-12 Plant Manager

\section{$\frac{3 / 29 / 96}{\text { Date Signed }}$}

Note: Both signatures have been notarized per requirements.

NOTARY

(Stamp/Seal)
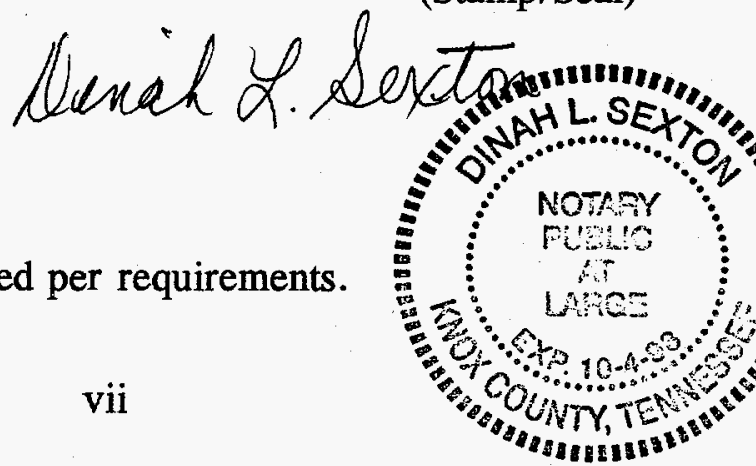


\subsection{INTRODUCTION}

\subsection{PURPOSE AND SCOPE}

The purpose of this document is to present potentiometric, groundwater quality, and vapor monitoring data required for site status monitoring of underground storage tank (UST) 0134-U at the Oak Ridge Y-12 Plant Building 9204-2 Site. Site status monitoring has been conducted at the site as part of a Monitoring Only program approved by the Tennessee Department of Environment and Conservation (TDEC) based on review and approval of Site Ranking (Site Ranking Form approved March 9, 1995). This document presents the results of the second semiannual site status monitoring that was performed in March 1996. Site ranking, as part of the Monitoring Only Program, has also been performed using the March 1996 groundwater data. Site status monitoring and preparation of this report have been conducted in accordance with the requirements of TDEC Rule 1200-1-15 and the TDEC UST Reference Handbook, Second Edition (TDEC 1994) Technical Guidance Document (TGD) 007.

This document is organized into three sections. Section 1 presents introductory information relative to the site including the regulatory initiative and a site description. Section 2 includes the results of water level measurement and sampling of monitoring wells GW-204, GW-656, GW-805, GW-806, and GW-807. Section 3 presents data from vapor monitoring conducted in subsurface utilities present at the site.

\subsection{SITE DESCRIPTION}

The Building 9204-2 Site is located within the central portion of the Oak Ridge Y-12 Plant in Oak Ridge, Tennessee (Figure 1-1). This area is within the Protected Area of the Y-12 Plant, which is access restricted. The UST site is generally defined as the area directly east of Building 9204-2 and southwest of Building 9720-30 (Figure 1-2). The site was previously the location of a gasoline UST used to fuel an emergency generator at Building 9204-2. The tank has been excavated and removed from the site.

The UST was a 117-gallon gasoline tank that was first suspected of leaking in 1988. Tank 0134-U was excavated on August 26, 1988, and several small holes were observed in the tank wall during removal. Initial Abatement/Tank Removal and Site Investigation/Environmental Assessment sampling indicated no presence of petroleum contamination in soil above applicable TDEC Closure Action Levels, but petroleum contamination of groundwater above applicable TDEC Closure Action Levels was identified. A Corrective Action Plan (CAP) for groundwater remediation was prepared and approved, and Baseline Monitoring was performed in August 1993 in support of corrective action. Baseline monitoring data were submitted to TDEC in March 1994 as part of a Closure Report. Additional soil and groundwater samples were collected to support Site Ranking before determining the disposition of the site. These samples indicated that contaminant concentrations were sufficiently low and contaminant exposure sufficiently limited in extent to qualify for a Monitoring Only program in lieu of active remediation. 


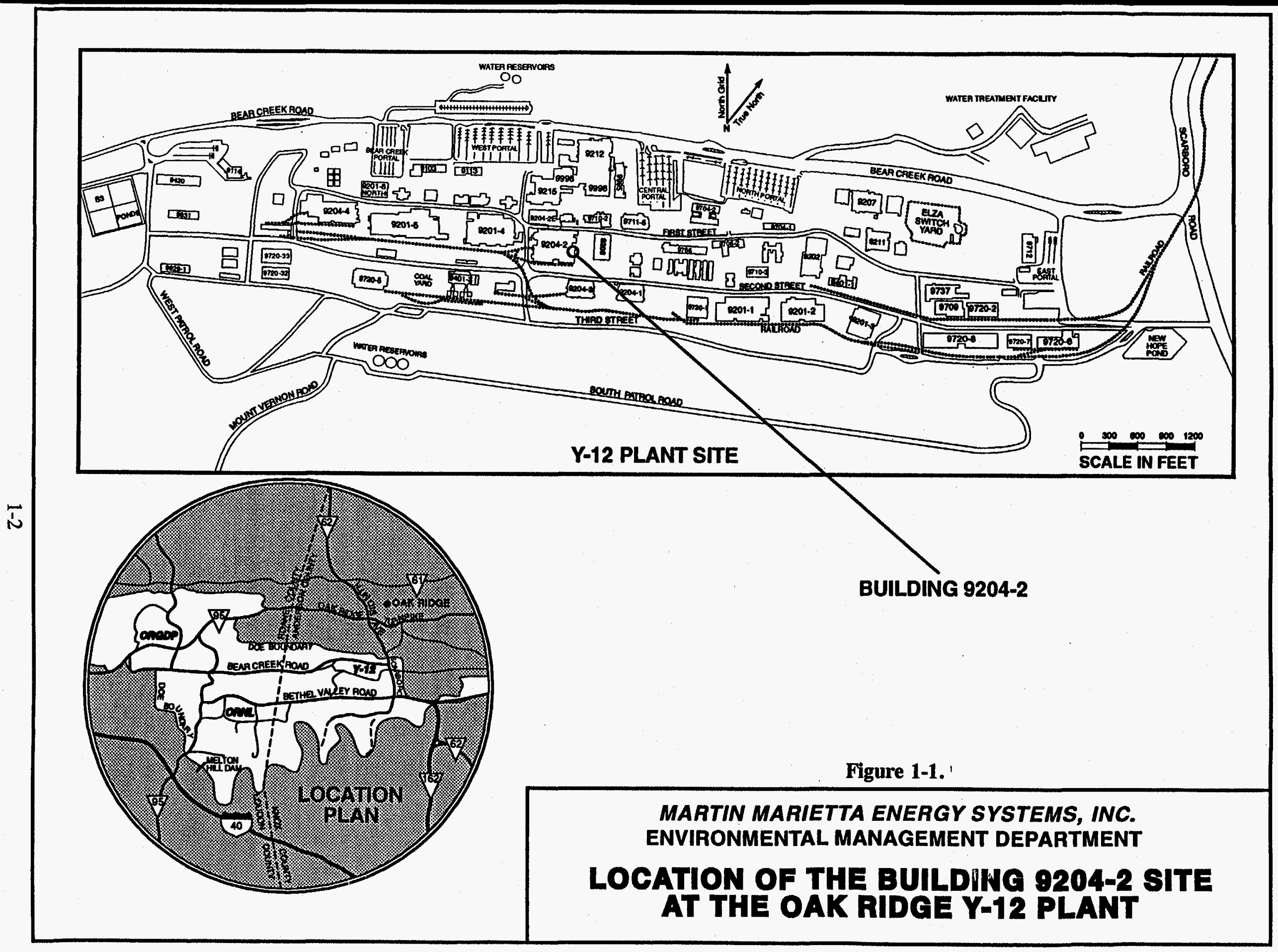




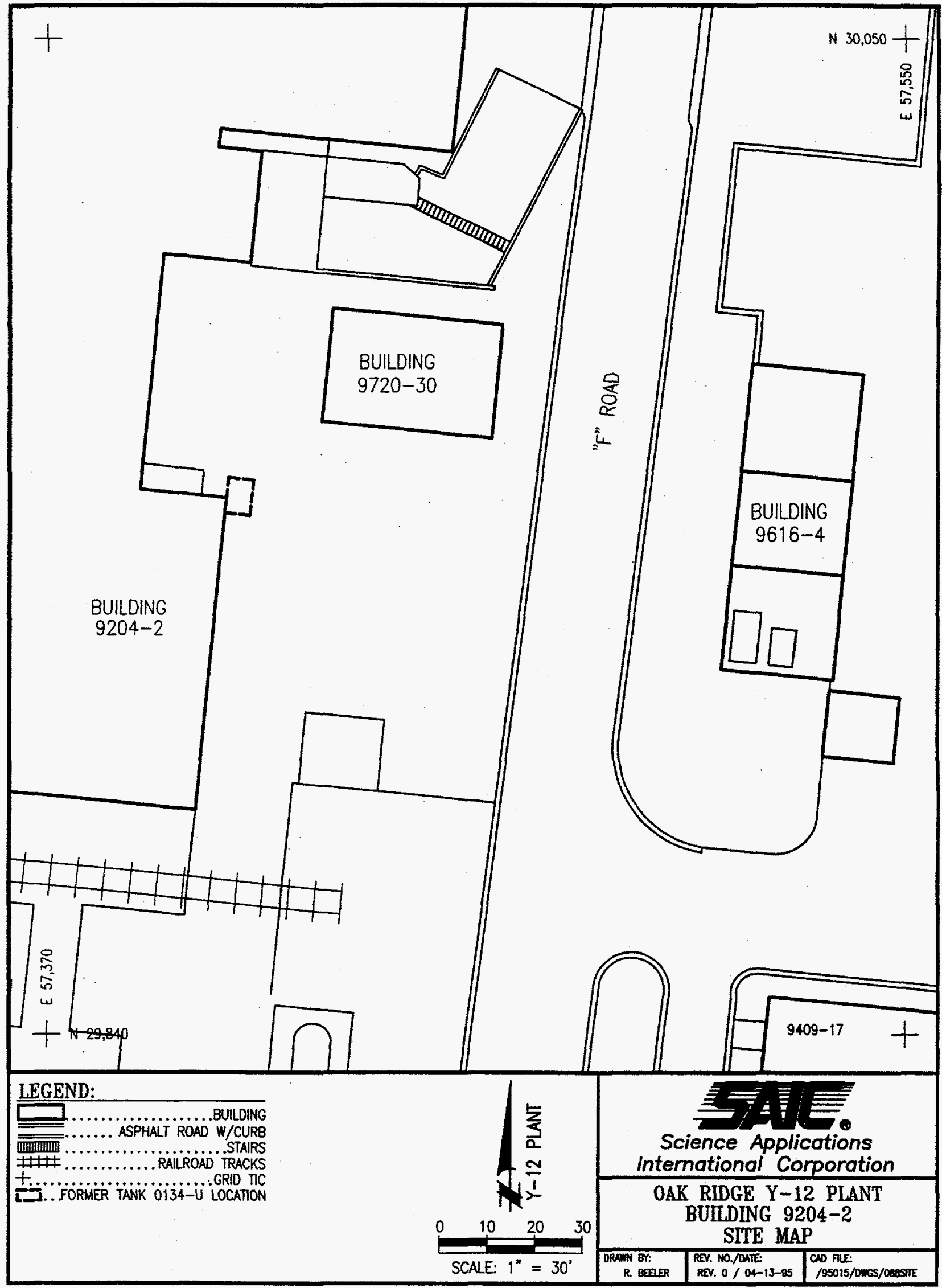

Figure 1-2. Building 9204-2 Site Map. 
The topography of the Building 9204-2 Site gently decreases in elevation from northwest to southeast across the facility. A surface water and groundwater divide coincident with the trace of Upper East Fork Poplar Creek (UEFPC) lies approximately $700 \mathrm{ft}$ southeast of the site. Given the nature of the surface topography in the vicinity of the Building 9204-2 Site, any petroleum contamination resulting from past UST operations would be expected to generally migrate southeast away from the source area. 


\subsection{GROUNDWATER MONITORING}

\subsection{GROUNDWATER MEASUREMENT, SAMPLE COLLECTION, AND ANALYSIS}

\subsubsection{Well Locations}

As directed by TDEC, all existing monitoring wells at the site have been measured and sampled as part of the Monitoring Only program. These wells are GW-204, GW-656, GW-805, GW-806, and GW-807. The locations of these wells are presented in Figure 2-1. Well installation reports and construction details for monitoring wells GW-204 and GW-656 are presented in the CAP for the Site [Corrective Action Plan for Underground Storage Tank 0134U at the Building 9204-2 Site, Appendix C, Y/SUB-92-99928C/4 (Energy Systems 1992)]. Well installation reports and construction details for monitoring wells GW-805, GW-806, and GW-807 that were installed in July 1993, are presented in the Closure Report for the Site [Closure Report for Underground Storage Tank 0134-U, Building 9204-2, Appendix B, Y/SUB/94-99069C/Y15/5 (Energy Systems 1994)].

\subsubsection{Groundwater Measurement and Sampling}

All groundwater monitoring wells at the Building 9204-2 Site were measured for water level and sampled for the applicable petroleum constituents on March 8,1996 as part of site status monitoring. All wells were measured for static water level and purged prior to sampling. Monitoring wells were purged of three well volumes except wells GW-204, which was purged to dryness after 2.0 well volumes, well GW-805, which was purged to dryness after 2.9 well volumes, and well GW-807, which was purged to dryness after 2.1 well volumes. Field measurement of $\mathrm{pH}$, conductivity, temperature, and dissolved oxygen was conducted during purging to ensure representativeness for sampling. Well GW-805 demonstrated elevated water temperatures, but all other parameters were generally consistent across the site. Wells purged to dryness were allowed to recover prior to sampling. The wells were sampled for analysis, using a bailer, and then collected into pre-prepared bottles. No measurable free product or odors were encountered during water level measurement or sampling in any of these wells.

\subsubsection{Sample Analysis}

Groundwater samples were analyzed for total petroleum hydrocarbons-gasoline range organics (TPH-GRO), and for benzene, toluene, ethylbenzene, and xylenes (BTEX) at the Y-12 Plant Environmental Laboratory (a TDEC Division of UST-approved laboratory). Analytical laboratory reports for groundwater sampled during site status monitoring (3/96) are included in Appendix A. 


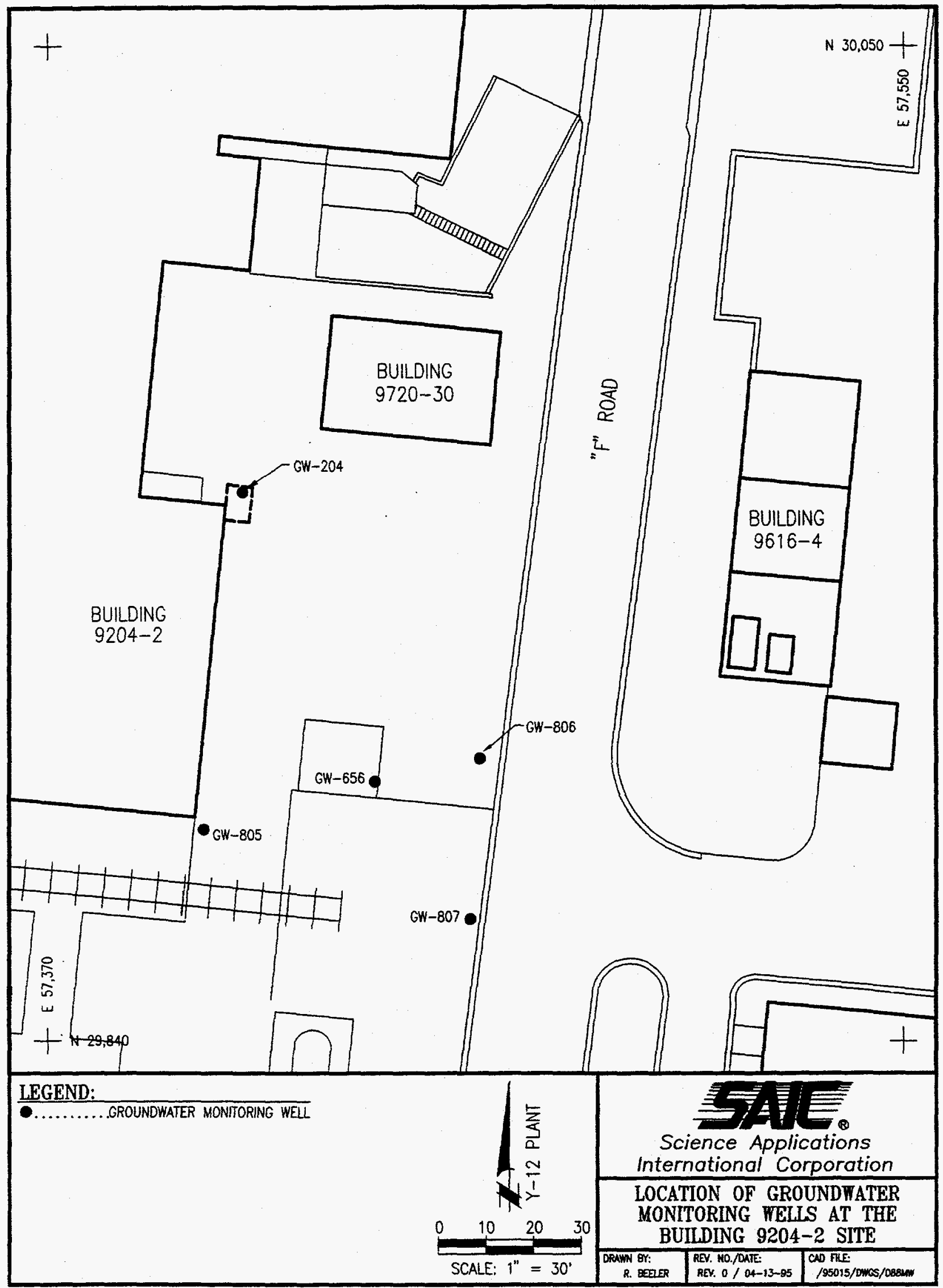

Figure 2-1. Location of Groundwater Monitoring Wells at the Building 9204-2 Site. 


\subsection{POTENTIOMETRIC DATA}

Potentiometric data for monitoring wells at the Building 9204-2 Site from site status monitoring (9/95 and 3/96) measurement events are presented in Table 2-1. Figures 2-2 and 2-3 present potentiometric contour maps from these two periods. These figures indicate the presence of a slightly irregular potentiometric surface with a generally east-southeasterly gradient. The apparent easterly deflection of the potentiometric gradient at the site may be due to small differences in head between unconsolidated and weathered bedrock wells and the degree of urbanization in this portion of the Y-12 Plant. The 800-series wells at the site were all completed in unconsolidated material at shallow depths [9.6-12.2 ft below ground surface (BGS)], whereas GW-204 and GW-656 were completed in weathered bedrock at 17.3 and 20.7 ft BGS, respectively.

Very little seasonal difference exists between the potentiometric surfaces and water levels in wells at the site remained consistent during this period. Studies of the Y-12 Plant hydrogeology indicate that an overall south/southeasterly hydraulic gradient is present in the unconsolidated and bedrock intervals at the Building 9204-2 Site (HSW 1994). Seasonal variation in groundwater elevations is small, but does appear to produce a localized southerly gradient in the northern portion of the site during wetter weather and a generally southeastern gradient in drier weather. Overall, groundwater flow at the site is to the east/southeast toward Upper East Fork Poplar Creek.

\subsection{GROUNDWATER ANALYTICAL DATA}

Analytical results for groundwater sampled at the site during site status and comprehensive monitoring, and site ranking are presented in Table 2-2. Analytical results indicate the presence of TPH-GRO groundwater contamination above the applicable TDEC Closure Action Level of $1.0 \mathrm{ppm}$ TPH at a single monitoring well (GW-656). Monitoring well GW-806 indicates the presence of TPH-GRO contamination above the analytical quantitation limit but well below the applicable TDEC Closure Action Level. Since GW-656 is bounded by the remaining four monitoring wells, the horizontal extent of TPH-GRO contamination in groundwater is well constrained. The level of TPH-GRO contamination is low, and the concentration of contamination has fallen off or remained the same over the past year. The extent of groundwater contamination has remained relatively stable at the site throughout the period monitored. This is consistent with previous monitoring results and the calculated hydraulic gradient, velocity, and conductivity from slug testing of wells GW-204 and GW-656 (Energy Systems 1992).

The analytical results do not indicate the presence of benzene contamination in any of the wells during site status monitoring. Quality control samples collected during this sampling include a duplicate (805A), a trip blank, and an equipment rinsate. Analytical results of quality control samples indicate the data presented in this report is reproducible and unaffected by cross- 


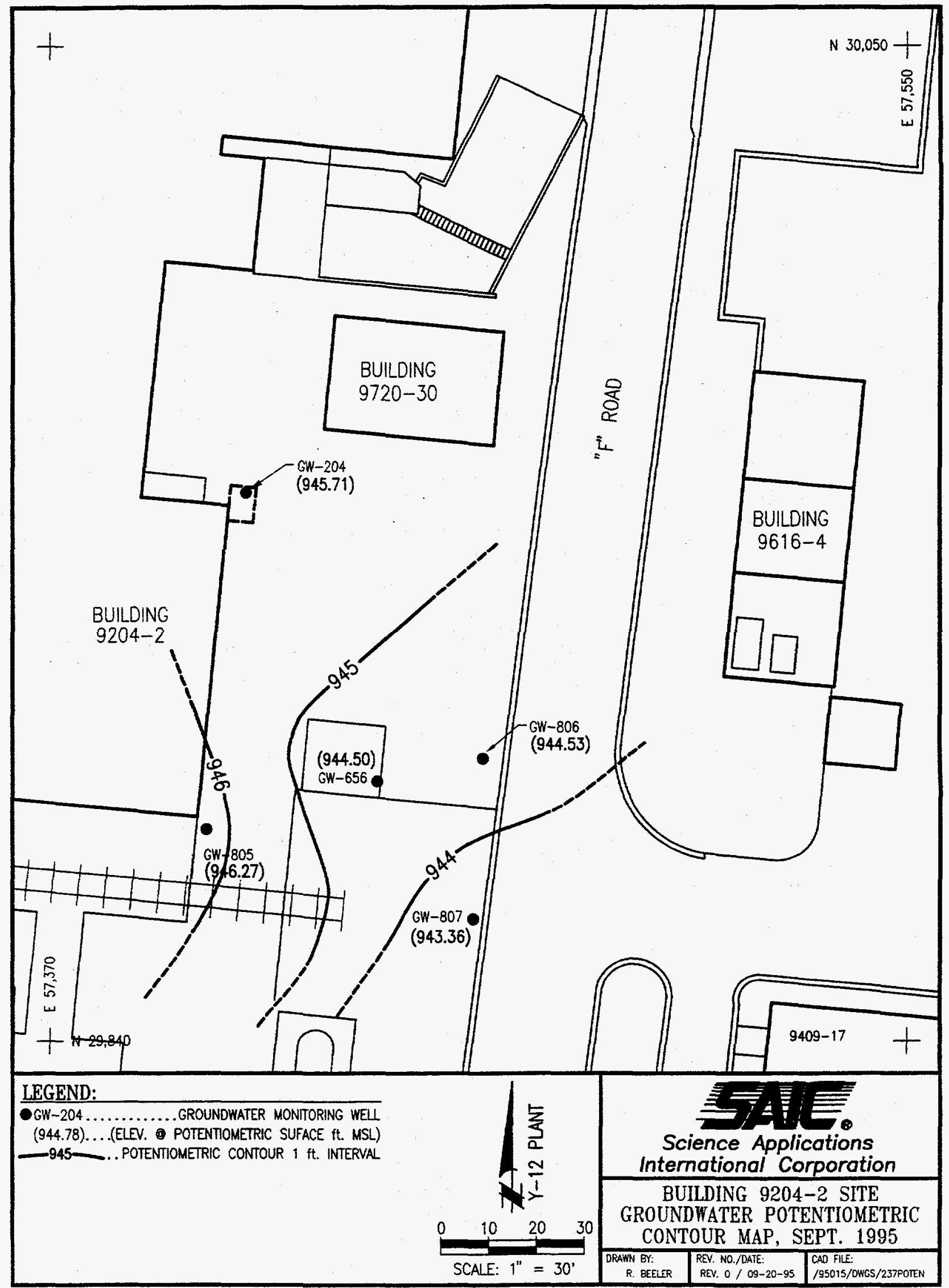

Figure 2-2. Building 9204-2 Site Groundwater Potentiometric Contour Map, Sept. 1995. 


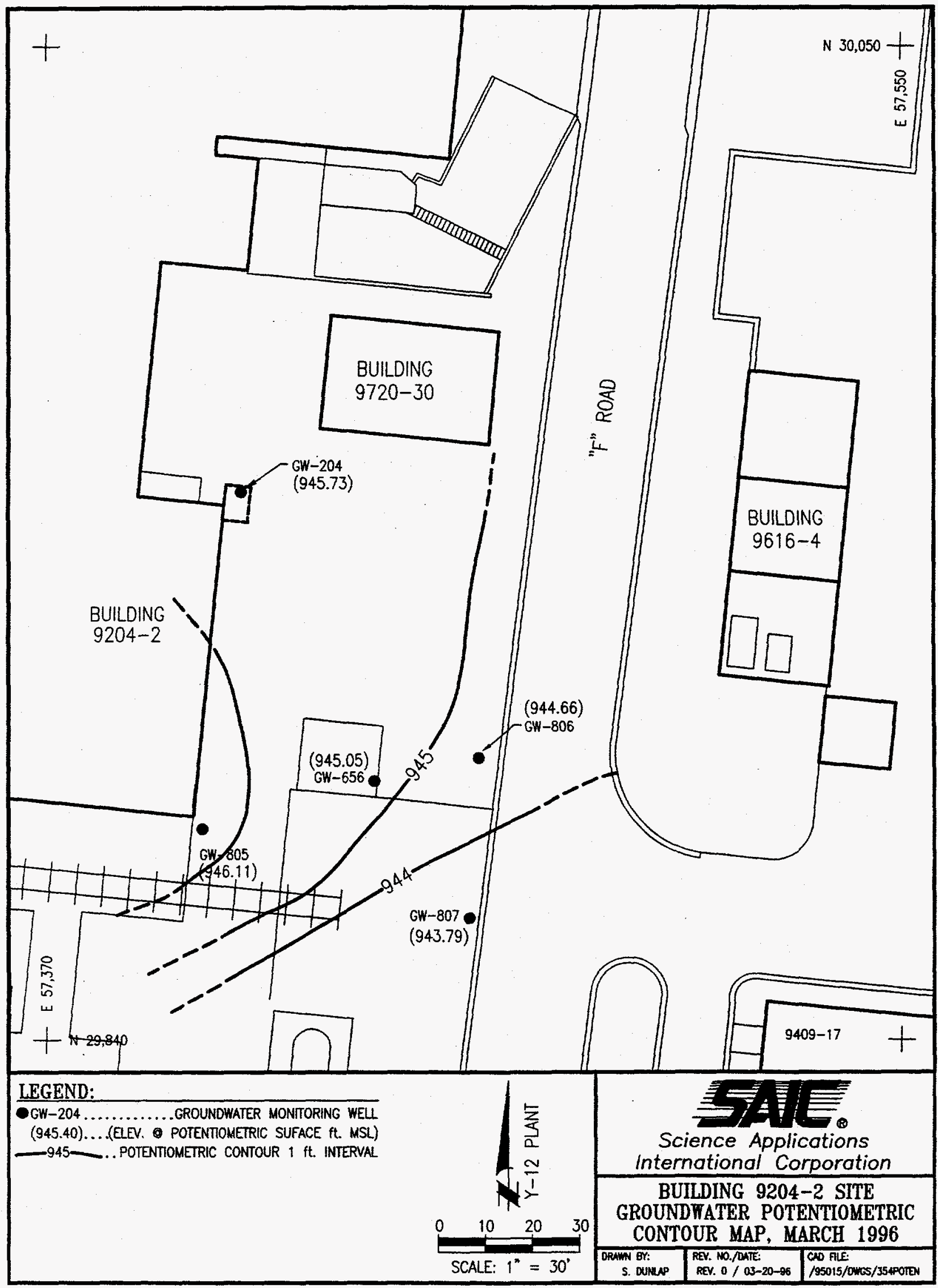

Figure 2-3. Building 9204-2 Site Groundwater Potentiometric Contour Map, March 1996. 
contamination. In general, it is expected that contaminant levels will fall off slowly as contaminant degradation proceeds because of the slow migration and limited mixing of the groundwater at the site. 
Table 2-1. Water Level Measurements at the Building 9204-2 Site for the Periods of March 1996 and September 1995

\begin{tabular}{|c|c|c|c|c|c|}
\hline $\begin{array}{l}\text { Monitoring } \\
\text { well number }\end{array}$ & $\begin{array}{c}\text { Date } \\
\text { measured }\end{array}$ & $\begin{array}{c}\text { Total well } \\
\text { depth } \\
\text { (ft-BGS) }\end{array}$ & $\begin{array}{l}\text { Top of } \\
\text { casing } \\
\text { (ft-MSL) }\end{array}$ & $\begin{array}{l}\text { Top of casing } \\
\text { to water level } \\
\text { (ft-BTOC) }\end{array}$ & $\begin{array}{l}\text { Potentiometric } \\
\text { surface elevation } \\
(\mathrm{ft}-\mathrm{MSL})\end{array}$ \\
\hline GW-204 & $\begin{array}{l}3 / 8 / 96 \\
9 / 7 / 95\end{array}$ & 20.3 & 955.47 & $\begin{array}{l}9.74 \\
9.76\end{array}$ & $\begin{array}{l}945.73 \\
945.71\end{array}$ \\
\hline GW-656 & $\begin{array}{l}3 / 8 / 96 \\
9 / 7 / 95\end{array}$ & 20.6 & 954.90 & $\begin{array}{c}9.85 \\
10.40\end{array}$ & $\begin{array}{l}945.05 \\
944.50\end{array}$ \\
\hline GW-805 & $\begin{array}{l}3 / 8 / 96 \\
9 / 7 / 95\end{array}$ & 11.6 & 955.02 & $\begin{array}{l}8.91 \\
8.75\end{array}$ & $\begin{array}{l}946.11 \\
946.27\end{array}$ \\
\hline GW-806 & $\begin{array}{l}3 / 8 / 96 \\
9 / 7 / 95\end{array}$ & 11.5 & 951.95 & $\begin{array}{l}7.29 \\
7.42\end{array}$ & $\begin{array}{l}944.66 \\
944.53\end{array}$ \\
\hline GW-807 & $\begin{array}{l}3 / 8 / 96 \\
9 / 7 / 95\end{array}$ & 14.0 & 955.36 & $\begin{array}{c}11.57 \\
12.0\end{array}$ & $\begin{array}{l}943.79 \\
943.36\end{array}$ \\
\hline
\end{tabular}

Notes:

BGS - below ground surface

MSL - mean sea level

BTOC - below top of casing 
Table 2-2. Analytical Results for Groundwater Samples Collected During Site Status and Comprehensive Monitoring, Site Ranking, and Baseline Sampling

\begin{tabular}{|c|c|c|c|c|c|c|}
\hline Sampling event & $\begin{array}{l}\text { Sampling } \\
\text { date }\end{array}$ & $\begin{array}{c}\text { TPH-GRO }^{1} \\
\text { (ppm) }\end{array}$ & $\begin{array}{c}\text { Benzene } \\
\text { (ppm) }\end{array}$ & $\begin{array}{c}\text { Ethylbenzene } \\
\text { (ppm) }\end{array}$ & $\begin{array}{c}\text { Toluene } \\
\text { (ppm) }\end{array}$ & $\begin{array}{c}\text { Xylenes } \\
\text { (ppm) }\end{array}$ \\
\hline \multicolumn{7}{|c|}{$G W-204$} \\
\hline $\begin{array}{l}\text { Site status } \\
\text { monitoring }\end{array}$ & $3-8-96$ & $<0.100^{2}$ & $0.010 \mathrm{U}^{3}$ & $0.010 \mathrm{U}$ & $0.010 \mathrm{U}$ & $0.010 \mathrm{U}$ \\
\hline $\begin{array}{l}\text { Site status } \\
\text { monitoring }\end{array}$ & $9-7-95$ & $<0.100$ & $0.010 \mathrm{U}$ & $0.010 \mathrm{U}$ & $0.010 \mathrm{U}$ & $<0.010$ \\
\hline $\begin{array}{l}\text { Comprehensive } \\
\text { monitoring }\end{array}$ & $3-29-95$ & 0.150 & $<0.010$ & $<0.010$ & $<0.010$ & $0.010 \mathrm{U}$ \\
\hline Site ranking & $9-2-94$ & $<0.100$ & $\begin{array}{l}0.010 \mathrm{U} \\
W-656\end{array}$ & $<0.010$ & $<0.010$ & $0.010 \mathrm{U}$ \\
\hline $\begin{array}{l}\text { Site status } \\
\text { monitoring }\end{array}$ & $3-8-96$ & $* 1.800$ & $<0.010$ & $0.010 \mathrm{U}$ & $0.010 \mathrm{U}$ & $0.010 \mathrm{U}$ \\
\hline $\begin{array}{l}\text { Site status } \\
\text { monitoring }\end{array}$ & $9-7-95$ & $* 1.800$ & $<0.010$ & $0.010 \mathrm{U}$ & $0.010 \mathrm{U}$ & $0.010 \mathrm{U}$ \\
\hline $\begin{array}{l}\text { Comprehensive } \\
\text { monitoring }\end{array}$ & $3-29-95$ & $* 2.300$ & $<0.010$ & $0.010 \mathrm{U}$ & $0.010 \mathrm{U}$ & $<0.010$ \\
\hline Site ranking & $9-2-94$ & $* 2.700 \mathrm{D}^{4}$ & $<0.010$ & $0.010 \mathrm{U}$ & $0.010 \mathrm{U}$ & $0.010 \mathrm{U}$ \\
\hline \multicolumn{7}{|c|}{$G W-805$} \\
\hline $\begin{array}{l}\text { Site status } \\
\text { monitoring }\end{array}$ & $3-8-96$ & $<0.100$ & $0.010 \mathrm{U}$ & $0.010 \mathrm{U}$ & $0.010 \mathrm{U}$ & $0.010 \mathrm{U}$ \\
\hline $\begin{array}{l}\text { Site status } \\
\text { monitoring }\end{array}$ & $9-7-95$ & $<0.100$ & $0.010 \mathrm{U}$ & $0.010 \mathrm{U}$ & $0.010 \mathrm{U}$ & $0.010 \mathrm{U}$ \\
\hline $\begin{array}{l}\text { Comprehensive } \\
\text { monitoring }\end{array}$ & $3-29-95$ & $<0.100$ & $0.010 \mathrm{U}$ & $0.010 \mathrm{U}$ & $0.010 \mathrm{U}$ & $0.010 \mathrm{U}$ \\
\hline \multicolumn{7}{|c|}{$G W-806$} \\
\hline $\begin{array}{l}\text { Site status } \\
\text { monitoring }\end{array}$ & $3-8-96$ & 0.160 & $0.010 \mathrm{U}$ & $0.010 \mathrm{U}$ & $0.010 \mathrm{U}$ & $0.010 \mathrm{U}$ \\
\hline $\begin{array}{l}\text { Site status } \\
\text { monitoring }\end{array}$ & $9-7-95$ & 0.110 & $0.010 \mathrm{U}$ & $0.010 \mathrm{U}$ & $0.010 \mathrm{U}$ & $0.010 \mathrm{U}$ \\
\hline $\begin{array}{l}\text { Comprehensive } \\
\text { monitoring }\end{array}$ & 3-29-95 & 0.160 & $0.010 \mathrm{U}$ & $0.010 \mathrm{U}$ & $0.010 \mathrm{U}$ & $0.010 \mathrm{U}$ \\
\hline Site ranking & $9-2-94$ & 0.290 & $0.010 \mathrm{U}$ & $0.010 \mathrm{U}$ & $<0.010$ & $0.010 \mathrm{U}$ \\
\hline
\end{tabular}


Table 2-2 (continued)

\begin{tabular}{llccccc}
\hline \multicolumn{1}{c}{ Sampling event } & $\begin{array}{c}\text { Sampling } \\
\text { date }\end{array}$ & $\begin{array}{c}\text { TPH-GRO } \\
(\mathrm{ppm})\end{array}$ & $\begin{array}{c}\text { Benzene } \\
(\mathrm{ppm})\end{array}$ & $\begin{array}{c}\text { Ethylbenzene } \\
(\mathrm{ppm})\end{array}$ & $\begin{array}{c}\text { Toluene } \\
(\mathrm{ppm})\end{array}$ & $\begin{array}{c}\text { Xylenes } \\
(\mathrm{ppm})\end{array}$ \\
\hline & & & & & & \\
& & & & & & \\
$\begin{array}{l}\text { Site status } \\
\text { monitoring }\end{array}$ & $3-8-96$ & $<0.100$ & $0.010 \mathrm{U}$ & $0.010 \mathrm{U}$ & $0.010 \mathrm{U}$ & $0.010 \mathrm{U}$ \\
$\begin{array}{l}\text { Site status } \\
\text { monitoring }\end{array}$ & $9-7-95$ & $<0.100$ & $0.010 \mathrm{U}$ & $0.010 \mathrm{U}$ & $0.010 \mathrm{U}$ & $0.010 \mathrm{U}$ \\
$\begin{array}{l}\text { Comprehensive } \\
\text { monitoring }\end{array}$ & $3-29-95$ & $<0100$ & $0.010 \mathrm{U}$ & $0.010 \mathrm{U}$ & $0.010 \mathrm{U}$ & $0.010 \mathrm{U}$ \\
\begin{tabular}{l} 
Site ranking \\
\hline \hline
\end{tabular} & $9-2-94$ & $<0.100$ & $0.010 \mathrm{U}$ & $0.010 \mathrm{U}$ & $0.010 \mathrm{U}$ & $0.010 \mathrm{U}$ \\
\hline
\end{tabular}

${ }_{1}^{1}$ TPH-GRO - Total Petroleum Hydrocarbons-Gasoline Range Organics.

$2<$ - Contaminant was not detected above quantitation limit during the analysis.

${ }^{3} \mathrm{U}$ - Contaminant was not detected above quantitation limit during the analysis.

${ }^{4} \mathrm{D}$ - Sample was diluted during analysis.

* Denotes contamination above the applicable closure action levels for the site. 


\subsection{VAPOR MONITORING}

\subsection{MONITORING METHODS AND LOCATIONS}

Vapor monitoring as part of site status monitoring was conducted at six access points along subsurface stormwater and sewer drainage lines in the vicinity of the Building 9204-2 Site. These points correspond to the points measured during comprehensive monitoring, and will be used throughout the Monitoring Only Program. However, none of the subsurface utilities present at the site cross the groundwater plume defined by the most recent data. The locations of vapor monitoring locations are illustrated in Figure 3-1.

At each location, the utility line and/or valve pit atmosphere was monitored using direct reading instruments. Organic vapors were measured using an organic vapor meter, and oxygen and lower explosive limit (LEL) were monitored with an MSA-260.

\subsection{VAPOR MONITORING RESULTS}

The results of site status vapor monitoring conducted March 12, 1996 at the Building 9204-2 Site are presented in Table 3-1. Measured oxygen percentages are within the range of normal air concentrations. LEL readings of $0 \%$ indicate that an explosion hazard does not exist within any of the monitored utilities. Organic vapor readings of 0.0 to $0.1 \mathrm{ppm}$ indicate no concentrations of volatile organic compounds above background are present in the utility line atmospheres.

Table 3-1. Vapor Monitoring Results for the Building 9204-2 Site, August 31, 1995

\begin{tabular}{cccc}
\hline $\begin{array}{c}\text { Sampling } \\
\text { location }\end{array}$ & $\begin{array}{c}\mathrm{O}_{2} \\
\%\end{array}$ & $\begin{array}{c}\text { LEL } \\
\%\end{array}$ & $\begin{array}{c}\text { Organic vapors } \\
\text { (ppm) }\end{array}$ \\
\hline B-1001 & 20.8 & 0 & 0.0 \\
B-1002 & 20.8 & 0 & 0.0 \\
B-1003 & 20.8 & 0 & 0.0 \\
B-1004 & 20.8 & 0 & 0.0 \\
B-1005 & 20.8 & 0 & 0.1 \\
B-1006 & 20.8 & 0 & 0.0 \\
\hline
\end{tabular}




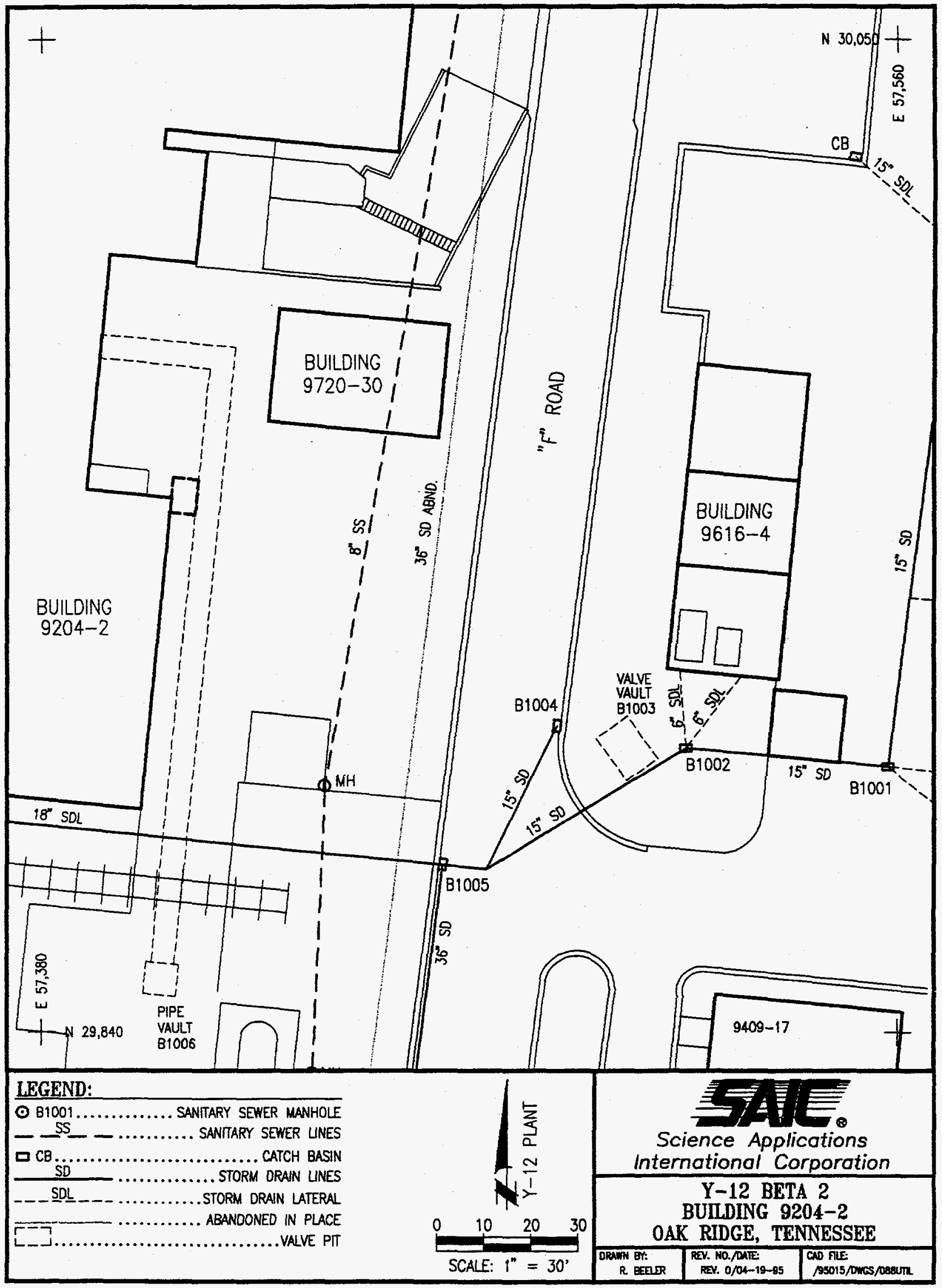

Figure 3-1. Organic Vapor Monitoring Points at the Building 9204-2 Site. 


\section{REFERENCES}

Energy Systems (Martin Marietta Energy Systems, Inc.) 1992. Corrective Action Plan for Underground Storage Tank 0134 $U$ at the Building 9204-2 Site, Y/SUB-92-99928C/4.

Energy Systems 1994. Closure Report for Underground Storage Tank 0134-U, Building 9204-2, Appendix B, Y/SUB/94-99069C/Y15/5.

HSW Environmental Consultants, Inc. 1994. Calendar Year 1993 Groundwater Quality Report for the Upper East Fork Poplar Creek Hydrogeologic Regime, Y-12 Plant, Oak Ridge, Tennessee, Y/SUB/94-EAQ10C/2/P1.

TDEC (Tennessee Department of Environment and Conservation) 1994. Underground Storage Tank Reference Handbook, Second Edition. 
APPENDIX A

LABORATORY ANALYTICAL RESULTS FOR

SITE STATUS MONITORING

GROUNDWATER SAMPLING 


\section{UNCLASSIFIED}

OFFICIAL REPORT

MITTER

riman, Donald Edwa

ADDRESS

Building 9115 Room 0102 M.S.8219

DATE NEEDED: $03 / 15 / 96$

DATE COMPLETED: 03/14/96

E RECEIVED: $03 / 08 / 96$

PPLER: 029776

\section{CUSTOMER ID \\ GW-204 \\ $\frac{\text { SAMPLE NO }}{\text { E960660000 }}$}

LOCATION: 9204-2 (GW-204)

PROJECT CODE:

FINAL APPROVAL:

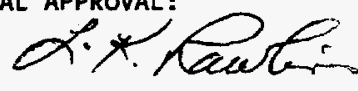

MTC STATUS

8601 APPROVED

CHARGE \#: S2205F29

CASE: U03117

MENTS: UST GROUNDWATER WELLS, 1 WEEK TURNAROUND/DON BOHRMAN. FAC.I.D.\#0-010117

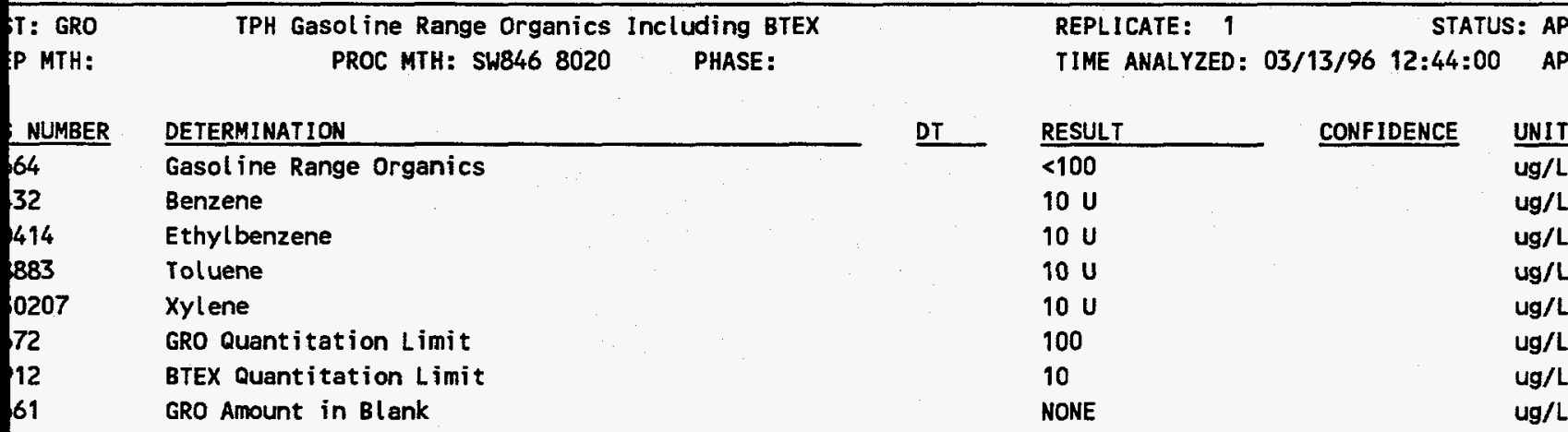




\section{UNCLASSIFIED}

OFFICIAL REPORT

$120 / 9616: 54: 25$

Y-12 ANALYTICAL SERVICES ORGANIZATION

PAGE 1 OF 1

BMITTER

Trman, Donald Edwa

ADDRESS

Building 9115 Room 0102 M.S.8219

TE SAMPLED: 03/08/96 13:22:00

DATE NEEDED: 03/15/96

DATE COMPLETED : 03/14/96

SAMPLE DESCRIPTION: GRAB IPLER: 029776 $\frac{\text { CUSTOMER ID }}{\text { GW-656 REQ NO }} \frac{\text { SAMPLE NO }}{\text { E960660001 }}$

LOCATION: $9204-2$ (GW-656)

PROJECT CODE:
MTC STATUS

8601 APPROVED

CHARGE \#: S2205F29

CASE: U03117

FINAL APPROVAL:

MMENTS: UST GROUNDWATER WELLS, 1 WEEK TURNAROUND/DON BOHRMAN. FAC. 1.D. \#0-010117

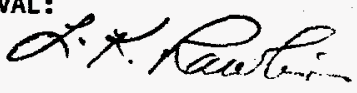

ST: GRO TPH Gasol ine Range Organics Including BTEX PROC MTH: SW846 8020 PHASE:
REPLICATE: 1

TIME ANALYZED: 03/13/96 13:20:00 APPROVER: E030124
DETERMINATION

Gasol ine Range Organics

Benzene

Ethylbenzene

Toluene

Xylene

GRO Quantitation Limit

BTEX Quantitation Limit

GRO Amount in Blank
DT

\begin{tabular}{l} 
RESULT \\
\hline 1800 \\
$<10$ \\
$10 \mathrm{U}$ \\
$10 \mathrm{U}$ \\
$10 \mathrm{U}$ \\
100 \\
10 \\
NONE
\end{tabular}

CONFIDENCE

UNIT

ug/L

$u g / L$

ug/L

$u g / L$

ug/L

$u g / L$

$u g / L$ 


\section{UNCLASSIFIED}

OFFICIAL REPORT

20/96 16:54:36

Y-12 ANALYTICAL SERVICES ORGANIZATION

PAGE 1 OF 1

\section{MITTER}

rman, Donald Edwa

ADDRESS

Building 9115

Room 0102 M.S.8219

DATE NEEDED: 03/15/96

DATE COMPLETED: 03/14/96

SAMPLE DESCRIPTION: GRAB PLER: 029776
CUSTOMER ID REQ NO SAMPLE NO GW-805A LOCATION: $9204-2$ (GW-805A) PROJECT CODE: E960660002

MTC STATUS

8601 APPROVED

CHARGE \#: S2205F29

CASE: U03117

FINAL APPROVAL:

MENTS: UST GROUNDWATER WELLS, 1 WEEK TURNAROUND/DON BOHRMAN. FAC. I.D.\# 0-010117

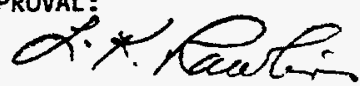

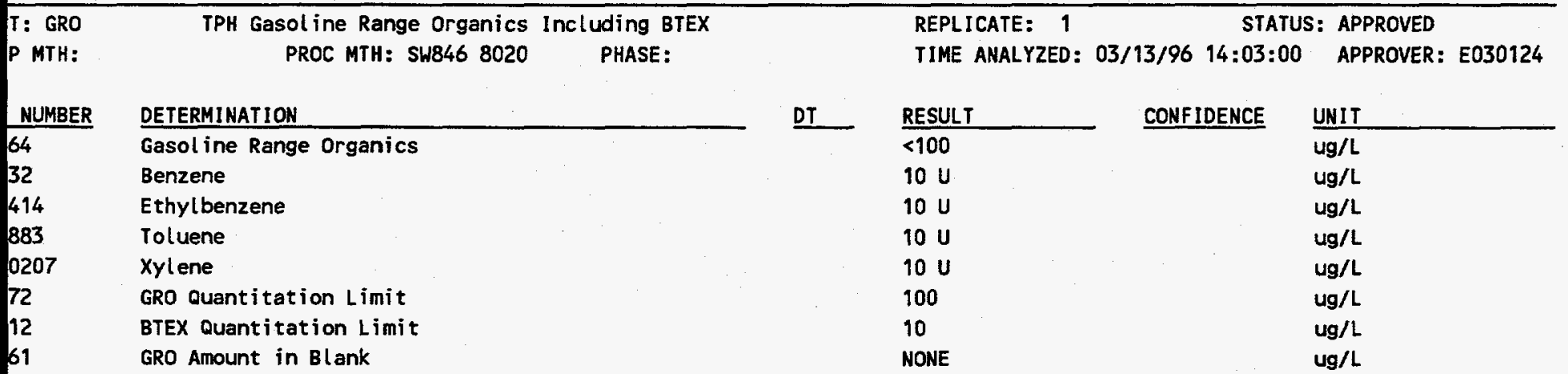




\section{UNCLASSIFIED}

OFFICIAL REPORT

120/96 16:54:43

Y-12 ANALYTICAL SERVICES ORGANIZATION

\section{BMITTER}

irman, Donald Edwa

JE SAMPLED: 03/08/96 13:33:00

TE RECEIVED: 03/08/96

APLER: 029776 $\frac{\text { CUSTOMER ID }}{\text { GW-805 }}$ REQ NO $\frac{\text { SAMPLE NO }}{\text { E960660003 }}$

LOCATION: 9204-2 (GW-805)

PROJECT CODE:
PAGE 1 OF 1

PACE 1 OF 1

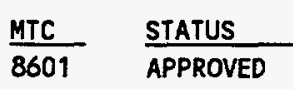

CHARGE \#: S2205F29

CASE: UO3117

MMENTS: UST GROUNDWATER WELLS, 1 WEEK TURNAROUND/DON BOHRMAN. FAC. I.D.\#0-010117

FINAL APPRQYAL:

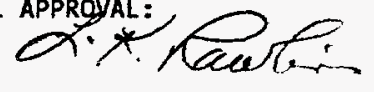

\begin{tabular}{|c|c|c|c|c|c|}
\hline $\begin{array}{l}\text { ST: GRO } \\
\text { FP MTH: }\end{array}$ & $\begin{array}{c}\text { TPH Gasoline Range Organics Including BTEX } \\
\text { PROC MTH: SW846 } 8020 \quad \text { PHASE: }\end{array}$ & & $\begin{array}{l}\text { REPLICATE: } 1 \\
\text { TIME ANALYZED: }\end{array}$ & $\begin{array}{l}\text { STATUS } \\
03 / 13 / 96 \quad 14: 38: 00\end{array}$ & $\begin{array}{l}\text { S: APPROVED } \\
\text { APPROVER: E030124 }\end{array}$ \\
\hline NUMBER & DETERMINATION & DT & RESULT & CONFIDENCE & UNIT \\
\hline 864 & Gasol ine Range Organics & & $<100$ & & $\overline{u g / L}$ \\
\hline+32 & Benzene & & $10 \mathrm{U}$ & & $u g / L$ \\
\hline 4414 & Ethylbenzene & & $10 u$ & & $u g / L$ \\
\hline 3883 & Toluene & & $10 \mathrm{U}$ & & $u g / L$ \\
\hline 30207 & Xylene & & $10 u$ & & $u g / L$ \\
\hline 72 & GRO Quantitation Limit & & 100 & & $u g / L$ \\
\hline 12 & BTEX Quantitation Limit & & 10 & & ug/L \\
\hline 61 & GRO Amount in Blank & & NONE & & ug/L \\
\hline
\end{tabular}




\section{UNCLASSIFIED}

OFFICIAL REPORT

$20 / 9616: 54: 56$

Y-12 ANALYTICAL SERVICES ORGANIZATION

PAGE 1 OF 1

\section{BMITTER}

irman, Donald Edwa

TE SAMPLED: 03/08/96 13:50:00

TE RECEIVED: 03/08/96

APLER: 029776

\section{ADDRESS}

Building $9115 \quad$ Room 0102 M.S.8219

DATE NEEDED: 03/15/96

DATE COMPLETED: $03 / 14 / 96$

SAMPLE DESCRIPTION: GRAB

\section{CUSTOMER ID R REQ NO \\ GW-806 \\ $\frac{\text { SAMPLE NO }}{\text { E960660004 }}$}

LOCATION: 9204-2 (GW-806)

PROJECT CODE:
FINAL APPROVAL:
MTC STATUS 8601 APPROVED CHARGE \#: S2205F29 CASE: U03117

MENTS: UST GROUNDWATER WELLS, I WEEK TURNAROUND/DON BOHRMAN. FAC. 1.0.\$0-010117

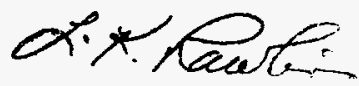

\begin{tabular}{|c|c|c|c|c|}
\hline $\begin{array}{l}\text { TT: GRO } \\
\text { P MTH: }\end{array}$ & $\begin{array}{l}\text { TPH Gasol ine Range Organics Including BTEX } \\
\text { PROC MTH: SW846 } 8020 \text { PHASE: }\end{array}$ & \multirow[b]{2}{*}{ DT } & \multicolumn{2}{|c|}{ REPLICATE: 1 STATUS: APPROVED } \\
\hline NUMBER & DETERMINATION & & CONFIDENCE & UNIT \\
\hline 364 & Gasol ine Range Organics & & 160 & $\mathrm{ug} / \mathrm{L}$ \\
\hline 32 & Benzene & & $10 \mathrm{U}$ & $\mathbf{u g} / \mathrm{L}$ \\
\hline 3414 & Ethylbenzene & & $10 U$ & ug $/ \mathrm{L}$ \\
\hline 8883 & Tolvene & & 10u & $\mathrm{ug} / \mathrm{L}$ \\
\hline 0207 & Xylene & & $10 \mathrm{U}$ & $u g / L$ \\
\hline 72 & GRO Quantitation Limit & & 100 & ug/L \\
\hline 12 & BTEX Quantitation Limit & & 10 & ug/L \\
\hline 61 & GRO Amount in Blank & & NONE & $\mathrm{ug} / \mathrm{L}$ \\
\hline
\end{tabular}




\section{UNCLASSIFIED}

OFFICIAL REPORT

MITTER

rman, Donald Edwa

ADDRESS

Building 9115 Room 0102 M.S.8219

E SAMPLED: 03/08/96 00:00:00

DATE NEEDED: 03/15/96

DATE COMPLETED: 03/14/96

SAMPLE DESCRIPTION: GRAB

PLER: 029776

\section{CUSTOMER ID REQ NO \\ GW-807}

LOCATION: $9204-2$ (GW-807)

PROJECT CODE: $\frac{\text { SAMPLE NO }}{\text { E960660005 }}$

INAL APPROVAL:
MTC STATUS

8601 APPROVED

CHARGE \#: S2205F29

CASE: UO3 117

MENTS: UST GROUNDWATER HELLS, I WEEK TURNAROUND/DON BOHRMAN. FAC. I.D. \#0-010117

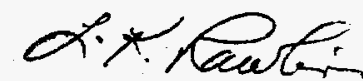

T: GRO TPH Gasoline Range Organics Including BTEX

PROC MTH: SW846 8020 PHASE:
REPLICATE: 1 STATUS: APPROVED

TIME ANALYZED: 03/14/96 10:51:00 APPROVER: E030124
DETERMINATION

Gasol ine Range Organics

Benzene

Ethylbenzene

Toluene

Xylene

GRO Quantitation Limit

BTEX Quantitation Limit

GRO Amount in Blank

\section{DT}

\begin{tabular}{l} 
RESULT \\
\hline$<100$ \\
$10 \mathrm{U}$ \\
$10 \mathrm{U}$ \\
$10 \mathrm{U}$ \\
$10 \mathrm{U}$ \\
100 \\
10 \\
NONE
\end{tabular}

CONFIDENCE

UNIT

ug/L

$u g / L$

ug/L

$u g / L$

ug/L

$\mathrm{ug} / \mathrm{L}$

$\mathrm{ug} / \mathrm{L}$

ug/L 


\section{UNCLASSIFIED}

OFFICIAL REPORT

BMITTER

irman, Donald Edwa

ADDRESS

E SAMPLED: 03/08/96 12:00:00

E RECEIVED: 03/08/96

IPLER: 029776

Building $9115 \quad$ Room 0102 M.S.8219

DATE NEEDED: 03/15/96

DATE COMPLETED: 03/14/96

SAMPLE DESCRIPTION: GRAB

\section{CUSTOMER ID EQPT. RINSE \\ REQ NO \\ $\frac{\text { SAMPLE NO }}{\text { E960660006 }}$} LOCATION: 9204-2 (EQPT.RINSE) PROJECT CODE:

FINAL APPROVAL:
MTC

8601

STATUS

CASE: U03117

MENTS: UST GW. WELLS EQPT. RINSE, 1 WK TURNAROUND/D.BOHRMAN. FAC.I.D.\#0-010117

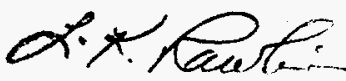

$\begin{array}{lc}\text { T: GRO } & \text { TPH Gasol ine Range Organics Including BTEX } \\ \text { P MTH: } & \text { PROC MTH: SW846 } 8020\end{array}$

REPLICATE: 1

STATUS: APPROVED

TIME ANALYZED: 03/14/96 11:27:00 APPROVER: E030124

DETERMINATION

DT

Gasol ine Range Organics

Benzene

\begin{tabular}{l} 
RESULT \\
\hline$<100$ \\
$10 \mathrm{U}$ \\
$10 \mathrm{U}$ \\
$10 \mathrm{U}$ \\
$10 \mathrm{U}$ \\
100 \\
10 \\
NONE
\end{tabular}

CONFIDENCE

UNIT

ug/L

$u g / L$

$\mathrm{ug} / \mathrm{L}$

ug/L

ug/L

$u g / L$

ug/L

$u g / L$ 


\section{UNCLASSIFIED}

OFFICIAL REPORT

MITTER

rman, Donald Edwa

ADDRESS

Building 9115

Room 0102 M.S. 8219

DATE NEEDED: 03/15/96

DATE COMPLETED: 03/12/96

E RECEIVED: 03/08/96

PLLR：029776

SAMPLE DESCRIPTION: GRAB

CUSTOMER ID
TRIP BLANK
LOCATION: 9207 (UST WELLS T.B)
PROJECT CODE:

FINAL APPROVAL:

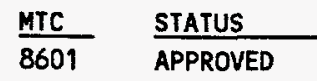

CHARGE \#: S2211601

CASE: U03117

MENTS: UST G.W. WELLS TRIP BLANK, 1 WK TURNAROUND/D.BOHRMAN. FAC. I.D.\#0-010117

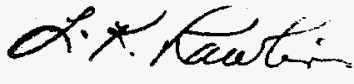

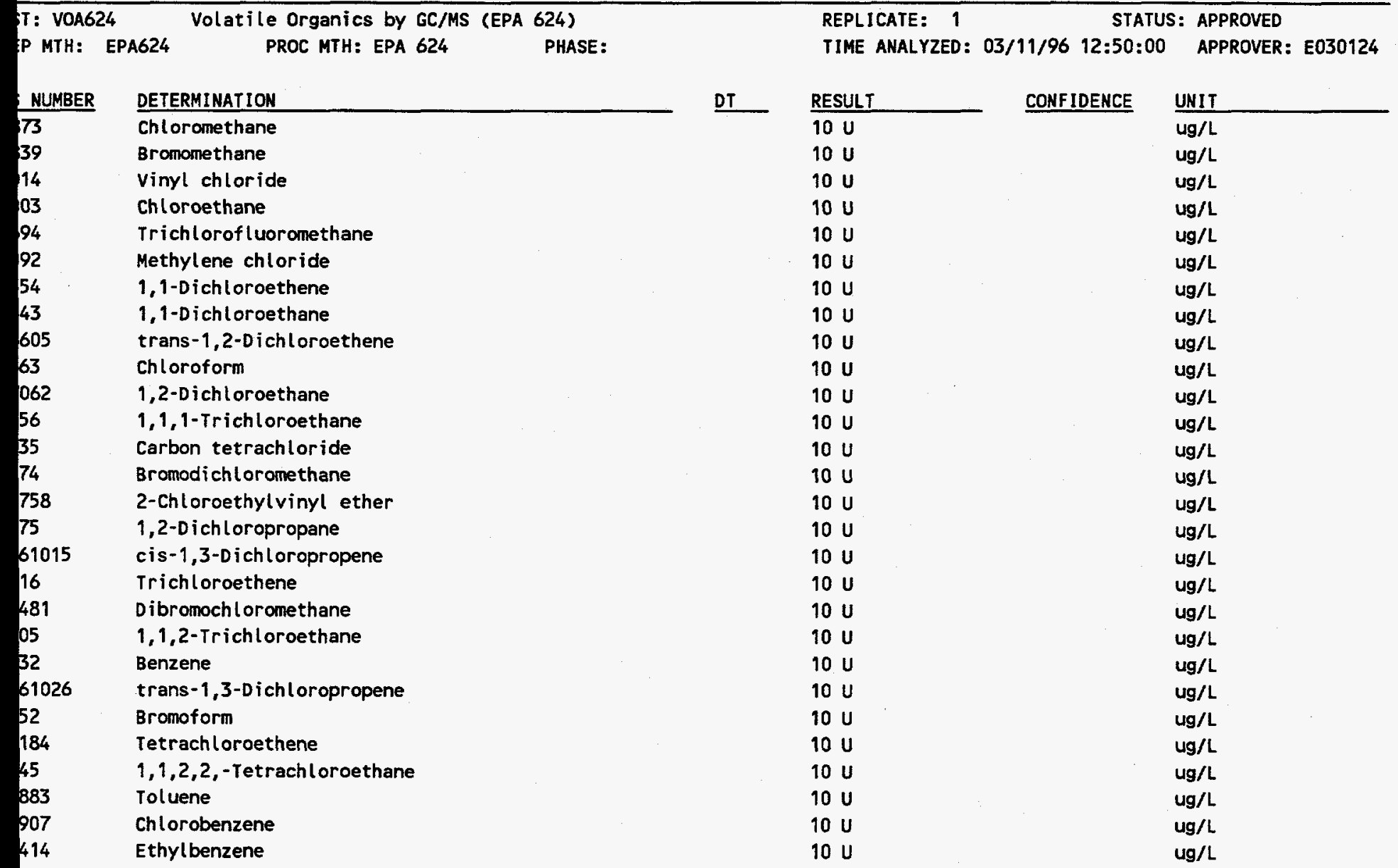




\section{DISTRIBUTION}

Health, Safety, Environment, and

Accountability Organization

U.S. Department of Energy

E.M. Ingram (3)

S.L. Lee

File - EMD - RC

R.J. Spence/L.M. Sparks

W.B. Mansel

Lithium Operations

A.K. Lee/DOE-OSTI (2)

Y-12 Central Files

R.C. Mashburn

Tennessee Department of Environment and Conservation

C. Head

E.C. Leming/J.D. Harless 